\title{
Mentoring for text editors: Fit for purpose in the era of freelancing, more so than alternative development strategies
}

\author{
John Linnegar \\ University of Antwerp, Stadcampus, Prinsstraat 13 R222, BE-2000, Belgium \\ E-mail: johndavid.linnegar@student.uantwerpen.be
}

\begin{abstract}
In this article, the supportive role that mentoring relationships currently do and should play in the development and careers of text editors is described against the background of the particular circumstances of these service providers in a sector experiencing great organisational and technological changes. This is a group that is much neglected in the literature on mentoring. Since the mentoring of text editors is distinct from other forms of mentoring in a number of key respects, this article draws together what the literature has to say about both conventional and online or distance mentoring as performed in a range of contexts. I consider the application of Knowles' $(1970,1984)$ adult learning theory and Bandura's (1977) self-efficacy mechanisms to be important potential contributors to the success of mentorships, in particular those involving adult text editors. The article also critically analyses how mentoring for text editors can be distinguished from alternative development strategies such as coaching, training, teaching and counselling. It shows that mentoring is fundamentally different from these strategies according to ten criteria, and is better suited to text editors' need for professional development as a form of lifelong adult e-learning. The lack of any form of assessment of mentees, in particular, is regarded as a weakness of the currently available mentorship programmes aiming to professionalise adult text editors through a process of lifelong learning.
\end{abstract}

Keywords: lifelong adult learning; mentee, mentor, mentorship programme; professional; selfefficacy; text editor

\section{Introduction}

Text editors who are members of five professional associations in Australia, Canada, South Africa, the United Kingdom (UK) and the United States (US) have access to the mentoring programmes provided by these associations. The programmes form a component of the professional bodies' total professional development offering. Besides mentoring, the labels these associations use to describe the various programmes include coaching, training and even counselling. This article describes and compares these development strategies with a view to understanding why mentoring, as defined in the literature, could be the most appropriate intervention for text editors. Given the circumstances in which they operate as freelance 
practitioners, the dearth of face-to-face mentoring opportunities in the sectors they service and the extent to which they have embraced information technologies, text editors should experience this form of distance learning as both conveniently accessible and able to raise their level of professionalism.

What we know about these mentoring programmes has to be gleaned principally from the websites and internal documentation of the professional associations, this sector being much neglected in the literature on mentoring. The mentoring programmes differ in some key respects, apart from association membership, the most significant being the barriers to entering a mentorship: from almost none (Australia: "some exposure to the basics of copy-editing and proofreading", through either work or training (IPEd 2015b)) to substantial (UK: "you must have had some initial training. You're normally expected to have successfully completed two SfEP training courses (in either copy-editing or proofreading) [and] show the necessary aptitude and sufficient knowledge to make the best use of mentoring, with a command of English well above average" (SfEP 2015a)). As a practising text editor and mentor in this sector, I have access to such information, and intend to use this intelligence to devise a model for webbased mentoring that includes a battery of suitable assignments and a system of assessment of mentees that will contribute to the standardisation of mentorships and their outcomes. Establishing the type of mentoring that best suits the needs and profile of text editors is the first step towards producing the model.

After describing the background to the need for the mentoring being offered by professional associations of text editors, this article describes the adult learning theories of Knowles (1970, 1984) and Bandura (1977) that synergise with the type of professional development offered by the mentoring programmes aimed at this group of practitioners. The article then focuses on distinguishing between mentoring, coaching, counselling, teaching and training as development strategies by comparing and contrasting them according to ten criteria (see below). Although it may comprise elements of these criteria, mentoring is shown to be a different intervention from the others in a number of respects. It is argued that mentoring is the most suitable strategy for developing text editors professionally, whether face to face or online. Citing the literature and the mentoring guidelines of the five professional associations (Canberra Society of Editors, Editors' Association of Canada (Toronto branch), Institute of Professional Editors, Professional Editors' Group (now Guild), Society for Editors and Proofreaders), a number of reasons for this are put forward. One of the points to emerge from this comparison is reiterated in the concluding section: that some form of formal or semi-formal post-mentoring assessment of mentees is missing from the different offerings, and this is contributing in part to the lack of a consistently high standard of service delivery by professional text editors.

\section{Background}

Unlike most other professions such as doctors, lawyers and architects, text editors are not currently obliged by law to register with a professional regulating body before they may offer their services to clients (cf. Kotzé 2012). Professional associations for text editors and proofreaders also do not set minimum standards of performance that their members must provide proof of attaining if they wish to practise their craft professionally. On the contrary, registration is voluntary, and membership of a professional association also does not guarantee its members work (CSE 2015, IPEd 2015a, PEG 2015, SfEP 2015a). Membership per se (other than advanced or accredited membership) also does not guarantee that members' output as text editors or 
proofreaders will be of a standard acceptable to clients. The voluntariness of membership of a professional association and the absence of a requirement of minimum standards of performance have led to a situation in which clients cannot be guaranteed editorial services of the highest standards. The professional associations for text editors in the English-speaking world are helping to fill this gap by providing voluntary mentoring programs (voluntary in the sense that text editors are not obliged to put themselves through them and the volunteer mentors are merely paid an honorarium for their participation).

The associations of editors' professional development offering to their members in Australia, Canada, South Africa, the UK and the US includes providing or recommending suitable training and networking opportunities, conferences, publications on relevant topics, chat groups, accreditation tests, graded levels of membership, and mentoring (ACES 2012; SfEP 2012a, 2012b; CSE 2014; EAC 2014; PEG 2014; IPEd 2015b). These activities - described in more detail in Linnegar (forthcoming) - are aimed at raising professional standards and promoting their members' services. Mentorships constitute a small but significant and much-needed aspect of this package of offerings. For the mentees who participate in them, they offer opportunities for upskilling, filling gaps in knowledge, obtaining advice on a range of matters, and personal growth, the summation of which is usually greater self-confidence and a higher level of performance (Levinson, Darrow, Klein, Levinson and McKee 1978; Tauer 1998; Murray 2001; Beagrie and Murray 2006; Manning Murphy 2012: 8, 35-36; Chen 2013: 199-200; Bloomberg 2014: 88-89; EAC 2014; Lepi 2014; Goldsmith and Marshall 2015).

It is particularly by providing mentorships that the professional associations have assumed the role of "learning organisations", previously the preserve of corporations and other institutions. In this role, they provide their members with opportunities for a form of lifelong learning (IPEd 2015b) that is aligned with both adult learning theory of the kind espoused by Knowles' (1970, 1984) "andragogy" and Bandura's (1977) self-efficacy mechanisms.

Knowles used andragogy as a concept to explain the conditions and principles for adult learning which include that adult learners: (i) have independent self-concepts and are thus led by selfdirectedness; (ii) draw on their accumulated reservoir of experience in their learning; (iii) are problem-centred and want to apply new knowledge immediately; (iv) need to know why they have to learn something before participating in learning, and (v) are motivated to learn by internal rather than external factors (Spies, Seale and Botma (in press), citing Knowles, Holton and Swanson 2005: 64-68). Andragogy emphasises the value of the process of learning (as mentoring is), which it regards as internal and self-directed (Knowles 1970, 1975, 1984). It is based on a belief that adults like to be given the opportunity to use their existing foundation of knowledge and experience gained from life and apply it to new learning experiences (Knowles 1978), as well as the belief that adults are goal- and relevancy-oriented. Accordingly, andragogy uses approaches to learning that are problem-based and collaborative rather than didactic, and also emphasises greater equality and collaboration between teacher and learner.

Mentorships for adult editors take these principles into account in confirming and extending editors' knowledge and skills, bringing their experience into play in their work and providing them with tasks that are challenging. They serve to help editors meet their expressed goals and are relevant to the field in which they wish to work. They also aptly describe the needs of text editors requiring mentoring. 
In essence, Bandura (1982) and others have found that an individual's self-efficacy plays a major role in how goals, tasks and challenges are approached. People with a strong sense of self-efficacy, therefore, tend to view challenging problems as tasks to be mastered, develop a deeper interest in the activities in which they participate, form a stronger sense of commitment to their interests and activities, and recover quickly from setbacks and disappointments (Bandura 1977). In contrast, people with a weak sense of self-efficacy tend to avoid challenging tasks, believe that difficult tasks and situations are beyond their capabilities, focus on personal failings and negative outcomes, and quickly lose confidence in their personal abilities (Bandura 1977). They need to be exposed to what Bandura terms "social modelling", "social persuasion" and "mastery experiences" of the kind that a mentor-role model can offer a mentee (Bandura 1989).

In the 21st century, self-efficacy has become additionally important for text editors for two reasons. First, many have had to take charge of their careers, because in the new corporate business environment of publishing, where time is money and lifelong learning is increasingly becoming a process external to publishing houses, mentoring as a means of professional development has shifted to become the text editor's responsibility. Secondly, text editors are expected to work semi-independently and take editorial decisions or persuade writers of the correctness of their decisions (Mackenzie 2011: 1-2, 49, 51, 201; Manning Murphy 2012: 4-9). They are also required to deal assuredly with difficult texts and challenging writers backed by a strong commitment to improving texts for publication, a firm grasp of normative linguistics (Van de Poel, Carstens and Linnegar 2012) and recourse to authoritative resources. They should therefore possess a strong sense of self-efficacy. This is one aspect of a mentee's makeup that a mentor should attend to, basing their support on Bandura's self-efficacy mechanisms (Bandura 1977, 1989; Manning Murphy 2012).

Mentoring based on the learning principles and concepts of Knowles $(1970,1984)$ and Bandura (1977) is suited to the needs of Editors 1-4 described below - especially when they have few, if any, experienced colleagues to turn to for personal support, guidance, feedback on their skills, confidence-building and career development opportunities.

To contextualise the particular form of mentoring being examined in this article, I begin by briefly sketching four fairly typical scenarios (based on real practitioners whom I have mentored):

- Editor1 is an aspirant text editor in her twenties who has recently completed an industryrecognised training course in text editing and proofreading. She aspires to pursue a career in the field as a freelancer without first gaining any inhouse experience. Without any inhouse contacts and apart from attending further training courses, she has few opportunities to develop her knowledge, skills and confidence (or self-efficacy) other than joining a professional association and considering a mentorship.

- Editor2 has been working as a copy editor in a publishing house for several years, but corporate downscaling has forced him into a new professional life as a freelancer. This will mean relinquishing the peers and informal mentoring contacts he has built up inhouse. The organisation will now become one of his clients with certain expectations of his service levels. His challenge is to seek out ways of continuing to develop and find someone who will serve as his role model or mentor now that he no longer has more experienced senior colleagues to turn to. 
- Editor3 is the chief editor of a small editorial division within a major organisation. As head of her team and with no-one with any linguistic or editorial inclinations outside the unit, she finds herself bereft of a mentor figure to consult. Her problem is one of obtaining the professional support she needs, external to her unit and organisation.

- Editor4 wishes to switch genres but is fearful of change. She is uncertain of her capabilities as a novice academic editor and is also concerned about being able to make a living from such editing after the security of working on school textbooks.

Mentoring seems to be an appropriate option for such editors, but why not coaching, counselling or training, for instance? To answer this question, I proceed now to define "mentoring" and distinguish it from other models of learning intervention and personal development. In the process, I consider what the mentoring of text editors comprises and how it differs from other mentoring interventions, before offering some concluding thoughts on the mentoring of text editors in particular.

A reason for making these distinctions is that in some professional associations mentoring is considered to be training or labelled as "coaching", which I and others believe is incorrect (SfEP 2012a, 2012b; EAC 2014; PEG 2014; IPEd 2015b). The methodology of the online mentoring model that will be the product of this research programme will bear the attributes of mentoring first and foremost.

In my view, the inventory presented below in response to these questions should form the foundation of any further programme development aimed at adequately answering the profession's needs for mentorships. I begin by asking how mentoring is uniquely different from other forms of learning, and where and when it can include elements of them.

\section{Mentoring: How it differs from coaching, counselling, training and teaching}

Although elements of coaching, counselling, training and teaching can be included in a mentorship (Murray 2001; Single and Muller 2001; Sparrow 2008; Manning Murphy 2012: 7-8; SfEP 2012a, 2012b), mentoring is essentially different from them in a number of fundamental respects (IPEd 2015b). The overview of the differences between the different teacher and learner relationships, drivers, processes and outcomes set out in Tables 1a-c is intended to clarify the distinctions between mentoring and the other developmental interventions.

This comparative-table format is adapted from Goodman (2009), whose objective was also to distinguish mentoring from other interventions, but in a secondary school teaching environment. He made a strong case for mentoring being different from coaching, counselling and training. All of Goodman's criteria for comparison, except "where the intervention takes place", are considered relevant to the one-on-one mentoring of text editors; examples of the relevant criteria include "the role-players", "who asks the questions", "who has the answers", and "who holds the power". For the purposes of my comparison, however, I added teaching as an intervention to contrast with mentoring (Manning Murphy 2012: 8) and also the following criteria: "function of the facilitator", "function of the learner", "learning mode", "unit of facilitation and who determines it", "means of assessment", and "consideration of greater self-efficacy as outcome". All of these criteria, I believe, help to deepen our understanding of the distinctions between the interventions and provide for a clearer differentiation between mentoring and the other professional development strategies. The criteria are arranged in three broad groups: 
- Table 1a: the role players in each relationship; who poses and answers questions; who holds the power or status in the relationship; the functions of the facilitator and the learner;

- Table 1b: the mode of learning; the unit of facilitation and who determines it;

- Table 1c: the means of assessment; and the outcomes, in particular the extent to which selfefficacy is one.

The items in the tables below are examined more closely, criterion by criterion. Table 1a is considered first.

Table 1a: Overview of the drivers, processes and outcomes in mentoring, coaching, training, teaching and counselling: the role players and their functions

\begin{tabular}{|c|c|c|c|c|c|}
\hline & MENTORING & COACHING & COUNSELLING & TRAINING & TEACHING \\
\hline Role players & Mentor and mentee & $\begin{array}{c}\text { Coach and } \\
\text { coachee }\end{array}$ & $\begin{array}{l}\text { Counsellor and } \\
\text { client }\end{array}$ & $\begin{array}{l}\text { Trainer and } \\
\text { trainees }\end{array}$ & $\begin{array}{l}\text { Teacher and } \\
\text { students }\end{array}$ \\
\hline $\begin{array}{l}\text { Questions } \\
\text { posed by ... }\end{array}$ & Mentee and mentor & Coachee & $\begin{array}{l}\text { Client and } \\
\text { counsellor }\end{array}$ & Trainees & Students \\
\hline $\begin{array}{l}\text { Answers } \\
\text { provided by ... }\end{array}$ & Mentee and mentor & Coach & $\begin{array}{l}\text { Client and } \\
\text { counsellor }\end{array}$ & Trainer & Teacher \\
\hline $\begin{array}{l}\text { Power/status } \\
\text { held by ... }\end{array}$ & $\begin{array}{l}\text { Mentee-driven; equal } \\
\text { status }\end{array}$ & Coachee & Counsellor & Trainer & Teacher \\
\hline $\begin{array}{l}\text { Function of } \\
\text { facilitator }\end{array}$ & $\begin{array}{l}\text { More holistic: } \\
\text { Transfer skills and } \\
\text { knowledge } \\
\text { Develop career } \\
\text { Counsel psychosocially } \\
\text { Act as role model }\end{array}$ & $\begin{array}{l}\text { Rectify specific } \\
\text { problems or } \\
\text { weaknesses in } \\
\text { coachee }\end{array}$ & $\begin{array}{l}\text { Deal with and help } \\
\text { resolve specific } \\
\text { problems of } \\
\text { client }\end{array}$ & $\begin{array}{l}\text { Transfer } \\
\text { knowledge and } \\
\text { skills to } \\
\text { trainees }\end{array}$ & $\begin{array}{l}\text { Transfer } \\
\text { knowledge } \\
\text { and skills to } \\
\text { students }\end{array}$ \\
\hline $\begin{array}{l}\text { Function of } \\
\text { learner }\end{array}$ & $\begin{array}{l}\text { Hone skills and acquire } \\
\quad \text { knowledge } \\
\text { Develop career } \\
\text { Achieve specific goals } \\
\text { Gain self-efficacy }\end{array}$ & $\begin{array}{l}\text { Seek to rectify } \\
\text { specific } \\
\text { problems or } \\
\text { weaknesses }\end{array}$ & $\begin{array}{l}\text { Seek or follow } \\
\text { counsel in } \\
\text { dealing with and } \\
\text { resolving own } \\
\text { specific } \\
\text { problems }\end{array}$ & $\begin{array}{l}\text { Acquire and } \\
\text { master } \\
\text { knowledge } \\
\text { and skills }\end{array}$ & $\begin{array}{l}\text { Acquire } \\
\text { and master } \\
\text { knowledge } \\
\text { and skills }\end{array}$ \\
\hline
\end{tabular}

\subsection{The role players}

Mentoring is a particular kind of relationship that an inexperienced person (a protégé or mentee such as Editorl described above) enters into in order to gain knowledge, skills, attitudes and values under the guidance and advice of a more experienced colleague (the mentor) who has significant and valuable experience in a similar type of work (Levinson et al. 1978, Tauer 1998, Ragins and Cotton 1999, Murray 2001, Beagrie and Murray 2006, Chen 2013: 199-200, Bloomberg 2014: 88-89).

The ideal mentor-mentee relationship should be one-on-one, bi-directional, egalitarian and learnerdriven (IPEd 2015b). For instance, the mentee should set the goals and the pace (ATA 2012, StJean 2012: 204, PEG 2013, CSE 2014), though the process should be closely monitored by the mentor, if only to maintain the momentum. This is in contrast to the other interventions, where coach, trainer, teacher and counsellor are more likely to apply set goals and control the pace. Here, the relationship is often not a collaborative one between equals; in the case of training and teaching, moreover, the relationship is one to many and typically uni-directional. 


\subsection{Who poses the questions and who provides the answers}

Goodman (2009) suggested that it is the mentee who asks and the mentor who answers questions. However, mentoring relationships based on adult learning principles in which transformative learning is expected to take place either synchronously or asynchronously (Bach, Haynes and Lewis-Smith 2007: 167) are not as rigid or as clear-cut as this: in a process of give and take (Ryan 2006), the parties are expected to both ask and answer questions, with the mentor encouraging the mentee preferably to reflect on matters and to answer their own questions, since learning is seen to be an internal process (Knowles 1970) that should lead to greater self-efficacy (Bandura 1977, 1982). Knowles' andragogy uses approaches to learning that are problem-based and collaborative rather than didactic, and also emphasises greater equality and collaboration between the teacher and the learner.

Relevant here are two of Knowles' $(1978,1984)$ six principles of adult learning, namely that adults are internally motivated and self-directed, and that they bring life experiences and knowledge to learning experiences - factors that are important to successful mentoring. Any questions the mentor asks should therefore prompt the mentee to arrive at their own solutions under the empathetic, respectful guidance of the mentor (Bach, Haynes and Lewis-Smith 2007: 167). This approach has been expressed by the professional associations in Canada, Australia and South Africa (PEG 2013, CSE 2014, EAC 2014). In the other, more uni-directional relationships, the learner normally has the questions to pose whereas the facilitator is usually in the position of providing answers, whether prompted or not.

\subsection{Power or status}

In a mentoring relationship, a mentor has no power over a mentee (Ryan 2006); indeed, whatever "power" there may be should be shared equally by the parties, the mentoring being essentially mentee-driven (PEG 2013, CSE 2014, EAC 2014) or "self-directed" (Knowles 1970, 1978). Status should be equal between mentor and mentee, the latter willingly entering into a mentorship with a particular mentor, and the mentor providing benign guidance to ensure that learning and growth take place most purposefully (Ryan 2006, EAC 2014) by covering the required knowledge and skills, social modelling and guiding the mentee as to appropriate psychosocial responses to situations (Bandura 1977, 1982, 1989; Ragins and Cotton 1999). The Institute of Professional Editors (IPEd 2015b) terms a mentorship "a two-way learning experience" from which both participants gain. The mentee and the mentor must also agree on the content to be covered formatively during a programme; on the proposed pace and timing they must also negotiate (Tauer 1998, Ryan 2006), and either party can decide on the point when their mentoring relationship should be terminated and what form the winding-up should take (Ryan 2006; SfEP 2012a, 2012b; PEG 2013; CSE 2014). This is in contradistinction to the other relationships represented in Table 1a, where the power is mostly in the hands of the facilitator and relationships are clearly delineated, the status of the participants being unequal.

Single and Muller (2001: 113-114) stress the importance of making suitable matches between mentors and mentees, especially in online relationships which many in the field of text editing are nowadays (SfEP 2012a, EAC 2014, PEG 2014, IPEd 2015b). In a corporate environment, Single and Muller (2001) point out, the participants usually have the corporate setting and culture in common, which is conducive to successful mentoring (though not devoid of questions of status or power); however, the partners in an online relationship lack this common ground - indeed, 
they may be situated in diverse cultures and environments (Single and Muller 2001: 113). Mentees should therefore be carefully matched with mentors by a mentoring administrator or committee (Single and Muller 2001: 113-114, Goodman 2009: 43). This can entail reviewing the mentoring profiles and making matches based on areas for development, mentor strengths, overall experience, skill set, location and the objectives of the mentorship. Assessing the mentor's skills and attributes is as important as assessing those of the mentee if a suitable match is to be made (Single and Muller 2001: 113-114, Ryan 2006, DoE 2008, PEG 2013, CSE 2014). For St-Jean (2012), working among independent entrepreneurs, the openness of a mentoring relationship is critical to its success if the mentee is to experience positive change. The mentee's self-disclosure is necessary, as such opening up leads to a deeper, evolving relationship based on trust and open communication, and also to a mentee's greater self-realisation by improving their selfunderstanding (Ellis 2000, St-Jean 2012: 204).

Nowhere is the irrelevance of power or status more starkly evidenced than in reverse mentoring, a relatively new phenomenon in which junior employees from Generations $\mathrm{X}$ and $\mathrm{Y}$, who possess advanced skills in information technology (IT), guide their seniors in the use of high-tech equipment, software and systems (Linnegar and Norenius 2012: 6, Chen 2013). With IT playing an increasing role in the production of publications - especially as digital publishing grows - reverse mentoring is becoming increasingly necessary as less IT-native text editors are confronted with and are having to become immigrants to challenging new technologies (Attwell 2014).

Mentors and mentees need to set expectations, goals and responsibilities for their relationships consensually, and to agree on couching them in confidentiality (Allen and Eby 2011: 357, ACES 2012). In this regard, seeking a mentor outside one's organisation is also considered advantageous (Beagrie and Murray 2006, Bloomberg 2014: 88), which should also pre-empt any power or status questions. Both of these conditions would be appropriate for Editor3, for instance.

Not being constrained by time and geography, and enabling status differences to become attenuated are also key characteristics and advantages of current online mentoring relationships between text editors (Single and Muller 2001: 107, Emelo 2011: 47-48, PEG 2013, CSE 2014, IPEd 2015b).

\subsection{Function of facilitator of learning}

Whereas the function of trainers and teachers is primarily to transfer knowledge and skills, coaches and counsellors help to identify, deal with and rectify specific problems or weaknesses that coachees and clients present with. In contradistinction, the mentor's role is more holistic, concerned with the development of the whole person, and so the techniques employed are broad and require wisdom in order to be used appropriately (Daloz 1990). Mentoring is essentially about facilitating change in individuals by providing a stable source of support through the process. Through interaction with mentors, mentees should be able to rehearse their actions, clarify their thoughts and gain feedback (St-Jean 2012).

A "package" of skills and knowledge transfer, career development, psychosocial counselling, emotional support (both work-related and personal) and the presentation of themselves as an experienced role model for the mentee should be included in the mentor's offering (Wright and Wright 1987: 205; Beagrie and Murray 2006; ACES 2012; Harriss and Harriss 2012; St-Jean 2012: 202, 203, 205-206; Chen 2013: 201-202; Bloomberg 2014: 90). They should focus on 
the individual and help them to use their strengths to achieve success (Ellis 2000). In this respect, the mentor is a substitute for the inhouse, on-the-job experience that text editors such as Editor2, in particular, would have had in the past. The mentor can also counsel or coach a mentee as and when the need arises: the stronger the support from the mentor, the firmer the relationship (Beagrie and Murray 2006, PEG 2013).

Kouzes and Posner (1993: 112) advise mentors to look for "teachable moments" in order to "expand or realise the potentialities of the people in the organizations they lead". These moments include monitoring their mentees gently to ensure that they also learn to deliver work on time (Ellis 2000, Single and Muller 2001, SfEP 2012a, PEG 2013, CSE 2014). Mossop (2010) takes this one step further when he says that an important distinction to make when teaching translation students is between things they need to know about and things they should actually be able to do in the workplace. For example, these students may know that a big problem in editing is passages whose meaning is obscure, but actually dealing with such passages when working on them is another matter. They also need to know that there is often not one best way to tackle a difficult text because, in reality, different professional editors work differently. So what teachers/mentors should be inculcating in learners/mentees is the internalisation of the procedures and principles for editing that can be applied long term rather than a mindset focused on achieving quick-fix results (Knowles 1970, Mossop 2010).

It has also been pointed out that the mentor is often the party who has to keep up the momentum of a mentor-mentee relationship (Single and Muller 2001, St-Jean 2012, PEG 2013, CSE 2014). Ellis (2000) emphasises that mentoring online requires constant vigilance of people whose lives are complex and busy and who risk either falling behind in the mentoring programme or discontinuing it, which is unsatisfactory if meeting deadlines is an important facet of mentoring. This view is supported by my experience of mentoring a number of mentees: it is so easy for either party to allow deadlines to slip, and so render the mentoring less effective. Sinclair (2003: 90), moreover, cautions mentors to be particularly sensitive when communicating with mentees online (via email or Skype) because she found it easier to encourage and support mentees, or gently challenge them, face to face than in writing.

\subsection{Function of learner}

Whereas the function of trainees and students is eventually to acquire and master knowledge and skills, that of the coachee and client is to seek to rectify specific problems or weaknesses or to seek professional counsel in dealing with them. The mentee, in contrast, will be looking to develop their career by broadening or refining their skills (e.g. specialising in editing law texts (Editor4), breaking into fiction editing or proofreading e-book texts) and gaining greater selfefficacy in the process (Bandura 1977, 1982). It is essentially a "one-to-one developmental relationship" (Beagrie and Murray 2006, DoE 2008: 7, Sparrow 2008) that gives the mentee the mentor's maximum attention. This is also in line with Knowles' $(1970,1978)$ principles of adult learning, where adults are goal- and relevancy-oriented, practical, and like to be respected.

Most text editors - such as Editors 1-4 - are adults by the time they require mentoring, all of them post-school, many of them with a first or second tertiary degree and some work experience. Furthermore, they have at least some exposure to their craft, are strongly motivated to improve authors' texts (a single-minded goal), bring a wealth of life experiences and knowledge to their work, are inclined to set store by the practical application of their knowledge and skills to 
enhancing texts, and regard earning respect as a key contributor to establishing a reputation for quality output and to achieving success in business. Knowles' $(1970,1978)$ principles are therefore aptly applicable to the mentoring of this group. In addition, much of the text editor's intervention to improve texts requires problem-solving and collaboration (Cubric, Clark and Lilley 2011: 136; Mackenzie 2011: 1-2, 49, 51, 201; Manning Murphy 2012: 4-9; Van de Poel, Carstens and Linnegar 2012: 19-21, 180, 194, 259-262).

The mentee should also be undergoing a type of action learning, a continuous process of learning and reflection that happens with the support of one or more colleagues working on real issues with the intention of getting things done (St-Jean 2012: 203). This would give the mentee increased responsibility for and control over their learning, and different pathways to knowledge (Brown and Thompson 1997, PEG 2013, CSE 2014, EAC 2014).

Text editors who require mentoring are typically either freelance service providers (Editor2) or full-time employees who no longer have direct access to a more experienced or expert colleague (Editor3) (ACES 2012, SfEP 2012a, PEG 2013, CSE 2014, EAC 2014). They therefore depend upon the professional associations of which they are members to be the catalyst in bringing suitable mentoring relationships into being. Such mentees can be either new to their craft (Editor1) or more experienced but wanting to hone their skills (Editors2-4), wanting to gain knowledge or develop their self-efficacy in order to sell their services to clients (Editor3). They have usually undergone at least basic training in text editing and/or proofreading (SfEP 2012a, PEG 2013, EAC 2014). They could have any number of mentoring goals, as Ryan (2006) says of translators: "[for example,] help with getting contacts, business advice, software training, marketing, practising their language skills, [wanting] the mentor to proofread their work, [and] to help the mentor with their workload [e.g. Editor3]. A lot of the time, the mentee just wants to be reassured that they're doing the right thing by going freelance and that their work is good enough".

There is consensus, at least among the Australian, Canadian and South African associations for text editors, that a mentorship should be mentee-driven: the mentee sets goals that become the basis of the pair's work together and in some associations is expected to set the pace too (PEG 2013, EAC 2014, IPEd 2015b). Those mentees with workloads also have to accommodate mentorships within full schedules and personal lives, and so mentors - themselves usually also busy individuals (Linnegar forthcoming) - have to take their competing commitments into account when setting assignments and negotiating deadlines and milestones (ATA 2012; SfEP 2012a, 2012b; PEG 2013; CSE 2014; EAC 2014; IPEd 2015b).

Freelance text editors, not fitting into an organisational structure other than their membership of a professional association, are more likely to experience the advantages (and some disadvantages) of a more semi-formal mentoring relationship that lies somewhere between strictly formal and informal (Lynn 1998), having some of the attributes of both. For one thing, the decision to be mentored is voluntary (Hutto, Holden and Haynes 1991; Harriss and Harriss 2012; St-Jean 2012: 202; PEG 2013; CSE 2014), as is the commitment of mentors who are experienced members of professional associations. Secondly, in contrast to corporate environments where HR departments tend to match-make (Harriss and Harriss 2012), the arrangement in which one user is matched with and assists another is also voluntary (Ehrich and Hansford 1999, Beagrie and Murray 2006) and is encouraged and facilitated by professional associations in the interests of both promoting individual development and enhancing 
professional skills and personal capabilities (SfEP 2012b; IPEd 2015a, 2015b). Ultimately, the profession as a whole benefits from individuals upgrading themselves: some mentors express the altruistic belief that they are contributing to professionalism in their sector as a whole by putting something back into their profession (cf. Beagrie and Murray 2006, Bloomberg 2014: 89, CSE 2014). This altruistic volunteerism also starkly sets the mentoring of text editors apart from the other developmental interventions.

Finally, by mutual agreement with their mentor and the programme's mentoring co-ordinator, the mentee may also terminate a partnership because they feel they have either achieved all they can from it or the partnership has achieved its goals, or because the mentorship is seen not to be working (Single and Muller 2001; SfEP 2012a, 2012b; PEG 2013; CSE 2014; EAC 2014). The mentee also negotiates the form that any winding-up should take (Ryan 2006; SfEP 2012a, 2012b; PEG 2013; CSE 2014).

The criteria in Table $1 \mathrm{~b}$, which compares the learning mode and the unit of facilitation across the different development strategies, are considered next.

Table 1b: Overview of the drivers, processes and outcomes in mentoring, coaching, training, teaching and counselling: the learning mode and unit of facilitation

\begin{tabular}{|c|c|c|c|c|c|}
\hline & MENTORING & COACHING & COUNSELLING & TRAINING & TEACHING \\
\hline Learning mode & $\begin{array}{l}\text { Lifelong, on the job, } \\
\text { from a mentor, } \\
\text { mentors or peers }\end{array}$ & $\begin{array}{l}\text { Sessions with } \\
\text { coach }\end{array}$ & $\begin{array}{l}\text { Sessions with } \\
\text { counsellor }\end{array}$ & $\begin{array}{l}\text { Short, fit-for- } \\
\text { purpose } \\
\text { courses }\end{array}$ & $\begin{array}{l}\text { Year-long in- } \\
\text { class and } \\
\text { homework }\end{array}$ \\
\hline $\begin{array}{l}\text { Unit of } \\
\text { facilitation ... }\end{array}$ & $\begin{array}{l}\text { No formal syllabus. } \\
\text { Specific text-based } \\
\text { editorial tasks as } \\
\text { determined by a } \\
\text { mentee's needs and } \\
\text { preferences }\end{array}$ & $\begin{array}{l}\text { Coach working on } \\
\text { 'problem' } \\
\text { or 'weakness' } \\
\text { that needs } \\
\text { remediation }\end{array}$ & $\begin{array}{l}\text { Counsellor } \\
\text { working on } \\
\text { client's specific } \\
\text { problem or } \\
\text { needs }\end{array}$ & $\begin{array}{l}\text { Syllabus, short } \\
\text { course } \\
\text { Group and } \\
\text { individual } \\
\text { work } \\
\text { Exercises }\end{array}$ & $\begin{array}{l}\text { Syllabus, } \\
\text { module, } \\
\text { degree } \\
\text { programme } \\
\text { Group } \\
\text { and individual } \\
\text { work } \\
\text { Exercises }\end{array}$ \\
\hline $\begin{array}{l}\ldots \text { and who } \\
\text { determines it }\end{array}$ & Mentee and mentor & Coach & $\begin{array}{l}\text { Counsellor and } \\
\text { client }\end{array}$ & Trainer & Teacher \\
\hline
\end{tabular}

\subsection{Learning mode}

\subsubsection{What sets mentoring apart}

This category is not included in Goodman's (2009) original table, and yet it strikes me as being another strong distinguisher of mentoring from the other developmental interventions.

Manning Murphy (2012: 8) is at pains to distinguish teaching from mentoring. Teaching means passing on knowledge and actively helping the learner to acquire a set of skills through concerted practice, testing their understanding and making sure that they are competent in applying those skills. Teaching, moreover, involves a more formal, uneven, even distant, relationship and process in which the teacher imparts knowledge and skills, the learner puts them into practice, and then the teacher assesses the practical-theoretical output. In such a relationship, the learner is often quite dependent upon the input of and assessment by the teacher, and eventually has to be weaned off that dependence. Achieving results (grades) tends 
to be an important focus of teaching, and the psychosocial development of learners as well as career guidance tend to be peripheral. Except for summative assessment, much of what applies to teaching applies also to training.

Mentoring text editors, on the other hand, entails guiding and encouraging a novice while they find their feet, helping them to gain experience, building their editing skills and thinking processes, and also allowing them to develop along their own lines (through a variety of techniques) towards greater self-efficacy and competence. It is a negotiation-led process that takes place less formally and uni-directionally than teaching, one in which the mentee acts, learns and develops more autonomously (Manning Murphy 2012: 8, 35-36). There is also more emphasis on formative assessment, the information gained from editing assignments to some extent guiding the next steps and possible additional learning opportunities needed to ensure success. In addition, mentoring allows for responsiveness to a perceived or real mentee need (e.g. Editors3, 4) (Lepi 2014) and entails giving feedback on which to build rather than on grades.

Although both involve one-on-one interventions, mentoring differs from coaching because the latter is more about performance and is therefore based on training specific skills or overcoming discrete problems whereas mentoring is more holistic and concerns the development of people (Sparrow 2008). The International Mentoring Association (2014), a US-based professional association serving mentors, defines coaching as "the support given for technical, skills-related learning and growth provided by another person who uses observation, data collection and descriptive non-judgemental reporting on specific requested behaviours and techniques". Coaching is therefore a much more narrowly focused activity than mentoring, being more concerned with performance (e.g. athletes, managers) and skills (e.g. mathematics or public speaking) (Goodman 2009).

In contrast, mentoring is the all-inclusive description of everything done to support mentee orientation and professional development. However, the International Mentoring Association (and others, e.g. DoE (2008)) views coaching as one of the sets of strategies that mentors should learn and use effectively to increase their mentees' skills and success, possibly to focus on a skill that needs developing or an attitude that has to be instilled or changed (IPEd 2015b). Editors 3 and 4, for instance, would benefit from coaching as they have never had experience in editing very long documents and need practice in doing so in order to master the strategy required to impose stylistic and structural consistency across tens of thousands of words.

Although both involve one-on-one interfaces, mentoring also differs from counselling, which focuses on specific psychological help, personal growth and career guidance. Counselling is also set apart in that it involves a trained professional counsellor (Goodman 2009), but an outcome it could have in common with mentoring is self-efficacy. For instance, Editor2, who is new to freelancing, could need to consult a professional on client relations, especially on dealing assertively with uncompromising authors.

Whereas training and teaching involve fairly limited time-based interventions that take place outside the workplace (e.g. short courses, degree programmes, etc.), mentoring is most typically based in the workplace and can be classified as lifelong, on-the-job learning. Even with online mentoring, mentor and mentee tend to be office-based, though in separate offices remote from each other. This is also the case with text editors, although they typically interact 
asynchronously and only virtually face to face, their communication taking place online, typically via either email or Skype.

Pursuing lifelong learning principles and objectives (IPEd 2015a), mentoring can be arranged as either long-term or short-term programmes according to mentees' specific needs (Ryan 2006; ACES 2012; SfEP 2012a, 2012b; PEG 2013; CSE 2014; EAC 2014). As conducted by professional associations for text editors such as SfEP, PEG and IPEd, these programmes are typically of about three to six months' duration, and during this period a total of between eight and 20 hours of "contact time" is allowed for by the different associations (cf. SfEP 2012a, PEG 2013, IPEd 2015b). Contact time is time during which mentor and mentee communicate about the mentee's assignments (suitable authentic texts that either the mentor has edited previously or that the mentee has acquired from a client), either orally or in writing or both, using electronic media (SfEP 2012a, PEG 2013, IPEd 2015b). Further mentoring time may be negotiated privately between mentor and mentee (SfEP 2012a, CSE 2014, PEG 2014, IPEd 2015b). Only in one instance (Op-Ed Project 2012) is a "mentorship" of very short duration and limited to one specific project: an "expert" journalist checking a fledgling writer's draft opinion-editorial (op-ed). Otherwise, in general, the duration of a mentorship should be "only as long as it takes for the mentee to achieve his/her goals" (Phillips-Jones 2001: 2, Beagrie and Murray 2006, Bloomberg 2014: 90). This cannot be said for coaching, teaching or training, which all take place within time and/or curriculum constraints.

The mentee's progress should be managed, usually through regular contact with their mentor (Sinclair 2003, Beagrie and Murray 2006, Goodman 2009: 43, Bloomberg 2014: 90). The role of the mentoring programme director or co-ordinator should simply be to monitor and record the progress of a mentorship and to be an arbiter should problems arise (SfEP 2012a, PEG 2013, CSE 2014, EAC 2014, IPEd 2015b).

\subsubsection{Mentoring as online learning}

As stated previously, much of the mentoring of text editors nowadays takes the form of online learning, distance learning or e-learning. Generally, online learning refers to the "delivery of a course via the web" (Emelo 2011: 48) via a number of media such as email, a website, Skype video conversations, tele- or videoconferencing, or social media such as Facebook, "with no significant difference in the quality of learning or overall satisfaction when people engage virtually versus in person" (Emelo 2011: 48). The benefits to the mentee of such online instructional design include: increased access to learning, asynchronous interactions, and flexibility of place, pace and interaction (Sherry 1996, Passerini and Granger 2000, PEG 2013, CSE 2014). Sinclair concludes (2003: 92) that, whereas technology cannot replace the affective nature of learning, it can nevertheless enhance the mentoring experience per se. The enhancement is likely when the tasks encourage higher-order thinking and substantive conversations among adult learners, and authentic assessment methods and tasks encourage mentees to put into practice what they have learned. This approach supports autonomous learning. This view is supported by Knowles' (1970) adult learning theory and is typical of much text editor mentoring (cf. SfEP 2012a, 2012b; PEG 2013; CSE 2014; IPEd 2015b).

Certainly, the Australian and South African programmes are evidence of multimedia making successful mentorships possible, using Skype, Skype Video, telephone, email and MS Word's Track Changes and Comments functions for written assignments (PEG 2014, Goldsmith and 
Marshall 2015, IPEd 2015b); SfEP (2012a) claims that "mentoring is typically done by email, so it is available anywhere in the world". Already, successful mentorships using multimedia are in place between continents: at the time of writing, two non-Australians are mentoring Australian practitioners, Australians are mentoring other Australians across different states as well as nonAustralians abroad, and within South Africa several mentors around the country are mentoring mentees who are geographically distant (PEG 2013, CSE 2014, IPEd 2015b), while one South African is being mentored by a mentor in Europe (PEG 2014) - all asynchronously.

Owing to their particular circumstances, for text editors mentoring has taken a form different from that encountered by other mentees in more structured organisations such as businesses, schools and universities. Until about the 1990s, the mentoring of many text editors took the form of informal inhouse superior-novice relationships within publishing houses, public relations practices or communications consultancies. There, less experienced practitioners could turn, as required, to more experienced colleagues for ad hoc information, opinions, advice and support (Beagrie and Murray 2006; DoE 2008: 20; Mackenzie 2011: 17, 19; Bloomberg 2014: 88, 90). Since the 1990s, however, businesses and educational institutions have been downsizing in order to reduce their overheads (DoE 2008: 16). In step with this, publishers worldwide have been shedding non-core staff (including text editors and proofreaders) and this has resulted in many editorial staff becoming freelance service providers, some of them servicing the very publishing houses that retrenched them (Editor2) (Mackenzie 2011: 199-200; Van der Poel, Carstens and Linnegar 2012: 149).

An important consequence of this recent trend has been to deny text editors the opportunity to enter into traditional informal mentoring relationships (Downie 2012, Van Loggerenberg 2012). These editors have effectively become the manager-entrepreneurs in their own businesses (not unlike Editors1, 2 and 4), a situation in which it is difficult to obtain psychological, career-related or role-model support from peers. They therefore have to obtain such support from an external mentor (St-Jean 2012: 203, IPEd 2015b) as it is not possible to enter into a mentoring relationship with a client. This is where professional associations of text editors have stepped into the breach: they have taken on the role of "learning organisations" (DoE 2008: 21, Bloomberg 2014: 89) formerly played by publishing houses in particular, and have set up mentoring programmes at either branch or national level (SfEP 2012a, PEG 2013, CSE 2014, EAC 2014, IPEd 2015b, SENSE 2015). Technological developments together with an increase in freelance service provision among text editors during the past two decades have combined to make online mentoring an attractive proposition for both the associations and text editors.

\subsection{The unit of facilitation and who determines it}

Once again, this factor was not used as a differentiating criterion in Goodman's (2009) summary, and yet in my view it makes for another critical distinction between mentoring and the other developmental interventions. In the case of training, the unit of facilitation can be a module of a course or a syllabus, and in teaching it can also be a module of an entire degree programme (Cubric, Clark and Lilley 2011: 134), including the assignments and projects that form part of the module. The content is usually prescribed by a standard-setting or examining body and implemented by the trainer or teacher, normally in line with a curriculum or syllabus. 
In contrast, in mentoring for text editors the content is "packaged" in limited units or specific assignments based on the mentee's expressed needs/goals - for example, texts to be corrected and otherwise improved in order to enable the mentee to practise specific editing skills and either apply or gain relevant knowledge (Editors1, 4). Mentee needs could include: being new to (and/or newly trained in) professional proofreading or copy-editing and needing exposure to or practice with real texts (SfEP 2012a, EAC 2014); more experienced text editors feeling that their skills and knowledge are rusty or patchy; wanting to move into editing a different genre of text (Editor4) (SfEP 2012a, PEG 2013, EAC 2014); wanting feedback from an experienced editor or proofreader regarding their ability (SfEP 2012a, IPEd 2015b); needing informal ad hoc advice, support, and/or encouragement without it being based on a specific document (Editor3), or on any document (e.g. advice on the business aspects of freelance editing (Editor2) (IPEd 2015b)). They may even need "reverse mentoring" (see section 3.3), where a less experienced person mentors a more experienced one in the mentor's area of expertise, for example using MS Word Styles or indexing or using macros to enhance the editing process (Linnegar and Norenius 2012: 5, Chen 2013, IPEd 2015b).

A basic assumption is that learning through either teaching or training interventions has been completed prior to the start of a mentorship (SfEP 2012a, PEG 2014, IPEd 2015b). The tasks are selected by negotiation between mentor and mentee, and are based on the mentee's particular needs and preferences (Ryan 2006, Linnegar and Norenius 2012, PEG 2013, CSE 2014) and their stated objectives for entering into a mentorship (Ryan 2006). Editor1, for instance, wants to focus on subediting and proofreading magazine articles, and so not only will her mentor have to have had experience or expertise in that genre or those particular skills, he or she will also have to help Editorl select suitable texts that expose her to them in the most realistic and practical of ways. In addition, sensitising Editor1 to the problems of plagiarism and defamation and the short turnaround times specific to this genre will form an important element of this mentorship. Plagiarism detection will also be an aspect of Editor4's mentorship, and she will require a mentor with considerable exposure to the intricacies of academic editing if their mentorship is to be productive

In the next two sections, the means of assessment and the consideration of greater self-efficacy as outcome are compared across the different interventions.

Table 1c: Overview of the drivers, processes and outcomes in mentoring, coaching, training, teaching and counselling: the means of assessment and consideration of greater selfefficacy as outcome

\begin{tabular}{|c|c|c|c|c|c|}
\hline & MENTORING & COACHING & COUNSELLING & TRAINING & TEACHING \\
\hline $\begin{array}{l}\text { Means of } \\
\text { assessment }\end{array}$ & $\begin{array}{l}\text { Systematic exposure to } \\
\text { and evaluation of } \\
\text { assignments (texts), } \\
\text { based on standard } \\
\text { criteria. No formal } \\
\text { evaluation }\end{array}$ & $\begin{array}{l}\text { Effectiveness of } \\
\text { remediation. } \\
\text { Extent to which } \\
\text { problem resolved }\end{array}$ & $\begin{array}{l}\text { Effectiveness of } \\
\text { remediation. } \\
\text { Extent to which } \\
\text { problem resolved }\end{array}$ & $\begin{array}{l}\text { In-course } \\
\text { exercises. } \\
\text { Post-training } \\
\text { assignments } \\
\text { (formal or } \\
\text { informal) }\end{array}$ & $\begin{array}{l}\text { In-class and } \\
\text { homework } \\
\text { assignments. } \\
\text { Tests, exam } \\
\text { (formal or } \\
\text { informal) }\end{array}$ \\
\hline $\begin{array}{l}\text { Consideration } \\
\text { of greater } \\
\text { self-efficacy } \\
\text { as outcome }\end{array}$ & $\begin{array}{l}\text { High: one-on-one } \\
\text { interface, with strong } \\
\text { input from mentee }\end{array}$ & $\begin{array}{l}\text { Low: one-on-one } \\
\text { interface }\end{array}$ & $\begin{array}{l}\text { Medium: one-on- } \\
\text { one interface }\end{array}$ & $\begin{array}{l}\text { Low: large } \\
\text { groups }\end{array}$ & $\begin{array}{l}\text { Low: large } \\
\text { groups }\end{array}$ \\
\hline
\end{tabular}




\begin{tabular}{|c|c|c|c|c|c|}
\hline & $\begin{array}{l}\text { Emphasis on: } \\
\text { Role-model nurturing } \\
\text { Challenging tasks, } \\
\text { problem-solving } \\
\text { Personal weaknesses } \\
\text { Opportunities for } \\
\text { positive outcomes } \\
\text { Confidence-building }\end{array}$ & $\begin{array}{l}\text { Greater focus on } \\
\text { remedying } \\
\text { specific problem } \\
\text { or weakness than } \\
\text { on building self- } \\
\text { efficacy }\end{array}$ & $\begin{array}{l}\text { Focus on specific } \\
\text { needs or } \\
\text { problems could } \\
\text { lead to growth } \\
\text { towards self- } \\
\text { efficacy }\end{array}$ & \begin{tabular}{|l} 
Greater \\
emphasis on \\
knowledge, \\
skills than on \\
building self- \\
efficacy
\end{tabular} & $\begin{array}{l}\text { Greater } \\
\text { emphasis on } \\
\text { knowledge, } \\
\text { skills. Less } \\
\text { chance to } \\
\text { develop } \\
\text { individuals' } \\
\text { self-efficacy }\end{array}$ \\
\hline
\end{tabular}

\subsection{The means of assessment}

Formative and summative assessment have already been alluded to. Both are critical to effective teaching and learning as, firstly, the student's progress must be monitored and decisions have to be made about the additional learning opportunities needed to ensure success. Secondly, both the teacher and students need information about the attainment of knowledge (usually measured by grades) and also an assessment of student learning by comparing their performance against some sort of standard or benchmark.

Formative assessment alone is more characteristic of short training courses and mentoring, where the same value is not generally attached to summative assessment. However, I would argue that for mentoring to be both effective and efficient, as a minimum, pre- and postassessments (or "measurement moments") should be put in place in order to assess/measure whether a mentee, after systematic exposure to and evaluation of a series of assignments, is able to display evidence of an improvement in their editorial proficiency. A tool should also be put in place to monitor a mentee's growth as they proceed through the assignments and the mentormentee exchanges during a mentorship (Linnegar forthcoming). What is more, a benchmark is required against which editorial proficiency can be evaluated, if the claim that a mentee has "successfully completed" a mentorship is to have any value.

On the available evidence, formal assessment is absent from the mentoring programmes of the professional associations for text editors. This makes objective measurement of the success of mentorships impossible and the competence levels of mentees in different countries, even between different mentors, highly varied (IHEP 2000).

Only SfEP currently has an evaluation system of sorts in place, but it has a different stated purpose: mentors grade candidates on a scale of 0 to 2 in each of five broad categories, and on the basis of their overall score (a maximum of 10) they may or may not qualify for an upgrade to a higher membership category. However, the criteria for and the form of assessment cannot be a thorough test of editorial competence; in addition, both appear to be highly subjective (cf. SfEP 2012a, 2012b).

The CSE/IPEd programme requires both the mentor and the mentee to evaluate their partner in a mentorship and the mentor to draft a detailed evaluation of the mentee at the end of a mentorship, using a standard form (CSE 2014, IPEd 2015b). The purpose of this evaluation is to assess the development of the mentee, the areas in which they will need to develop further, and the strengths and weaknesses of the particular relationship and the mentoring experience as a whole. Mentoring is also regarded as good preparation for the biennial accreditation examination that member-editors are encouraged to sit every two years (IPEd 2015b). 


\subsection{The extent to which self-efficacy as an outcome of mentoring is considered}

Outcomes are not included in Goodman's (2009) differentiating criteria and yet, once again, in my view they should be a set of critical distinguishers since the outcomes will surely vary between interventions and professional associations.

The Editors' Association of Canada (EAC 2014), for instance, declares the purpose of its programme to be to help "new or transitioning editors" to obtain advice, support and guidance from experienced editors with wisdom to share. The Institute of Professional Editors (IPEd 2015b) and the Professional Editors' Guild (PEG 2013) share this objective. In this sense, mentoring is a developmental relationship based on regular interactions through which the mentee gains skills, perspective and experience (Beagrie and Murray 2006, ATA 2012, PEG 2013, Bloomberg 2014, CSE 2014). At the same time, for the mentee, two important adjunct outcomes or benefits of entering into a mentoring relationship, broadly stated, are career advancement (Beagrie and Murray 2006, St-Jean 2012, Chen 2013: 199) and psychosocial support (identified as "encouragement, friendship, advice and feedback") (Kram 1985; Chen 2013: 199-201; Bloomberg 2014: 88). On the other hand, mentoring should not be viewed as a pathway to work, job shadowing, apprenticeship or an internship programme (Ryan 2006; SfEP 2012a, 2012b; PEG 2013; CSE 2014; EAC 2014; IPEd 2015a, 2015b).

In essence, self-efficacy is attained through a combination of mastery experiences, social modelling and social persuasion, and as such it is a good fit with the objectives of mentoring. If one considers self-efficacy as an outcome of a developmental intervention, then it will be attained to different extents with each type - from low at one extreme to high at the other (Table 1c). In the case of training and teaching, because they usually involve group interfaces during the transfer of knowledge and skills, with few opportunities for one-on-one interactions, the likelihood of striving towards and attaining higher levels of self-efficacy will more likely be low. The focus of coaching relationships is narrow (resolving specific problems or challenges) and they, too, are likely to lack the influences of at least social modelling and social persuasion, though there may be opportunities for mastery experiences. The likelihood of achieving self-efficacy during coaching has to be rated low. In the case of counselling, the likelihood will range between high and low because of the possibility (or not) of personal growth being an outcome of satisfying specific needs or resolving specific problems.

With mentoring (a one-on-one interface), working towards self-efficacy should be high on the continuum, because exposing the mentee to mastery experiences (e.g. Editor 1, 3 or 4 mastering a technique or a genre), social modelling and social persuasion (e.g. having benefitted from the feedback provided and the example set by their role-model mentor) should be standard in such a relationship if the mentee is to emerge with more than simply additional knowledge and skills.

Because text editors such as Editors1-4 are expected to work semi-independently in close collaboration with publishers and/or authors, firmly taking informed editorial decisions and often persuading authors and other role-players of the correctness of their decisions, it is necessary that they possess a strong sense of self-efficacy (Mossop 2010; Mackenzie 2011: 1-2, 49, 51, 201; Manning Murphy 2012: 4-9). The contributions mentors should make in this regard include: attempting to improve the self-efficacy of mentees by gently and supportively confronting mentees with challenging editorial tasks (SfEP 2012a, IPEd 2015b); focusing on mentees' interests and strengths and building on them; identifying weaknesses and helping to remedy them; 
creating opportunities for reflection and positive outcomes that help to build mentees' confidence in their ability to complete editorial tasks competently; and encouraging openness and questionraising without fear of loss of face (EAC 2014, PEG 2014, IPEd 2015b).

According to St-Jean (2012: 202-203), mentoring is more focused on a holistic quest for meaning than on pure skill building (the focus of other interventions), being firmly anchored in action. For this reason, it has been argued that training, coaching and counselling should not form the core offering or focus of mentorships, and that none of these interventions can be used interchangeably with mentoring (cf. IPEd 2015b).

\section{Concluding observations}

This article is an attempt to add to the literature on mentoring by providing some insights into the nature and content of the mentorships offered by five professional associations of text editors around the world. The mentoring of text editors is much neglected in the current literature. The mentorships described in this article are taking place in a landscape of fairly sweeping change: changes in the relationships between text editors and clients; change in the form of text editors being forced to become entrepreneurs while still needing support from industry peers; and sweeping changes in technology that are making communications between text editors, their clients and their peers more attenuated and asynchronous, both physically and temporally. Such changes also present opportunities, though, for those determined to ride the wave - including the opportunity for some form of distance learning or online mentoring across and between continents (Manning Murphy 2012, SfEP 2012a, PEG 2013, IPEd 2015b).

As far as mentoring is concerned, opportunities are currently limited to relatively few practitioners. During 2014, for example, PEG, whose members numbered 560, had fewer than 10 active mentorships in place (1.77\% of members; Downie 2014). In the case of SfEP, with its national membership averaging 2000 , only 29 mentorships were registered in $2013(1.45 \%$ of members), and only 55 in 2014 (2.75\% of members; SfEP 2015b). However, the introduction and implementation of an online blended model for autonomous adult learning (the larger project to which this article contributes) has the potential to increase access to online mentorships because of their convenience to practitioners and their asynchronous nature.

Given their circumstances, text editors have access to fit-for-purpose mentoring by fellow editors only through membership of professional associations; this serves to make them members of a professional community and in turn validates the profession (Kotzé 2012). Such voluntary mentorships are at best semi-formal, being mentee-driven though mentor-monitored. But whether or not they are members of an association, a not insubstantial group of adult text editors, with their personal and career developmental needs in their own hands, is in need of lifelong professional development or the equivalent of on-the-job learning opportunities that include role-modelling, networking, guidance on running a business and marketing (Sparrow 2008), and building their self-efficacy, inter alia by being challenged and supported by a mentor who provides developmental opportunities. This is where implementing the principles of Knowles' $(1970,1984)$ adult learning theory, as described and applied in this article, can make an invaluable contribution to text editors' success in delivering quality products to their clients (even while being mentored). 
It is generally acknowledged that distance or online learning presents challenges for participants (Sherry 1996; Ellis 2000; Passerini and Granger 2000; Single and Muller 2001; Sinclair 2003; Cubric, Clark and Lilley 2011). Mentees experience challenges related to technology (especially for IT non-natives), the distance between facilitator and learner (encounters being asynchronous and no longer face-to-face), and personal motivation (needing external stimuli such as peers, teachers, deadlines) (Sinclair 2003). However, applying Bandura's (1977) self-efficacy mechanisms - including a combination of mastery experiences, social modelling and social persuasion - in an online mentoring model should empower participants in mentorships to overcome such obstacles to lifelong learning more easily. This should be particularly true of individuals whose learning styles and needs are more suited to autonomous learning and focused on achieving success and whose strengths are used to achieve it (Ellis 2000).

Unlike learning interventions such as training and teaching, the semi-formal mentoring currently available to text editors is bound by neither syllabus nor curriculum, nor does it have any formal assessment component attached to it (or even informal assessment at best). As a result, it is not possible to benchmark mentees upon completion of a mentorship (IHEP 2000). This should be viewed as a flaw in a system that tends to militate against the professionalisation of text editors because of the lack of standardisation it leads to. It is a clear area for further research: into a standard assessment model that can be applied to editor-mentees in order to evaluate both their progress during mentoring and their level of editorial proficiency at the end of a mentorship. International best practice, clients and text editors themselves surely require this.

\section{References}

Allen, T.D. and L.T. Eby (Eds.) 2011. The Blackwell handbook of mentoring: A multiple approach. New Jersey: Blackwell Publishing.

American Copy Editors Society (ACES). 2012. Mentorship program. Available online: http://www.copydesk.org/programs/mentors/ (Accessed 18 August 2013).

American Translators Association (ATA). 2012. ATA mentoring program. Available online: https://www.atanet.org/careers/mentoring.php (Accessed 18 August 2013).

Attwell, A. 2014. Editing for the screen: Three things every editor should know about. Presentation at a PEG event on 11 December 2014, Cape Town, South Africa. Available online: www.editors.org.za (Accessed 17 December 2014).

Bach, S., P. Haynes and J. Lewis-Smith. 2007. Online learning and teaching in higher education. Open University Press.

Bandura, A. 1977. Self-efficacy: Toward a unifying theory of behavioral change. Psychological Review 84(2): 191-215.

Bandura, A. 1982. Self-efficacy mechanism in human agency. American Psychologist 37(2): 122-147.

Bandura, A. 1989. Exercise of control through self-belief. Current Contents 20: 14. 
Beagrie, S and F. Murray. 2006. How to find a mentor. Available online: http://www.personneltoday.com/hr/how-to-find-a-mentor (Accessed 11 December 2013).

Bloomberg, M. 2014. The role of mentoring. Physician Executive Journal 40(2): 88-90.

Brown, A. and H. Thompson. 1997. Course design for the WWW: Keeping online students onside. In R. Kevill, R. Oliver and R. Phillips (Eds.) $14^{\text {th }}$ annual conference proceedings for the Australian Society for Computers in Tertiary Education, What Works and Why? Perth: Curtin University of Technology. pp. 74-81.

Canberra Society of Editors (CSE). 2014. CSE-initiated national mentoring program: Guidance notes (including notes for mentors and mentees). Canberra: CSE.

Canberra Society of Editors (CSE). 2015. Canberra Society of Editors constitution. Available online: www.editorscanberra.org/about/constitution (Accessed 14 May 2015).

Chen, Y.C. 2013. Effect of reverse mentoring on traditional mentoring functions. Leadership and Management in Engineering 13(3): 199-208.

Cubric, M., K. Clark and M. Lilley. 2011. An exploratory comparative study of distancelearning programmes. Procs 10th European Conference on e-Learning: ECEL-2011. Berkshire, UK: Academic Conference Publishing International. pp. 134-144.

Daloz, L.A. 1990. Effective teaching and mentoring. San Francisco: Jossey-Bass.

Department of Education, South Africa (DoE). 2008. Mentor school managers \& manage mentoring programmes in schools. Available online: http://www.education.gov.za/LinkClick.aspx?fileticket= $\underline{60 \mathrm{wBdETqC} 2 \mathrm{o}}=($ Accessed 23 May 2014).

Downie, A.M. 2012. To serve and correct. PEGboard 19(2): 5.

Downie, A.M. 2014. PEG's 21-year journey: A timeline. PEGboard 21(3): 23.

Editors' Association of Canada (EAC). 2014. Toronto branch mentorship program (English/français). Available online: http://www.editors.ca/branches/toronto/mentoring program.html/ (Accessed 21 June 2014).

Ehrich, L.C. and B. Hansford. 1999. Mentoring: Pros and cons for HRM. Asia Pacific Journal of Human Resources 37(3): 92-107.

Ellis, K. 2000. A model class. Training 37(12): 50-57.

Emelo, R. 2011. Creating a new mindset: Guidelines for mentorship in today's workplace. Training and Development 6(1): 44-49.

Goldsmith, E. and J. Marshall. 2015. Getting the best out of mentoring: A mentor and mentee's experience. (Abstract). Available online: http://www.metmeetings.org/en/mentor-mentee:775 (Accessed 25 September 2015). 
Goodman, M. 2009. Mentoring. Johannesburg: Macmillan Expert Educator Series.

Harriss, S. and A. Harriss. 2012. Benefits of mentoring programmes in occupational health. Available online: http://www.personneltoday.com/hr/benefits-of-mentoring-programmes-inoccupational-health/ (Accessed 11 December 2013).

Hutto, N., J. Holden and L. Haynes (Eds.) 1991. Mentor training manual for Texas teachers. Dallas: Texas Education Agency.

Institute for Higher Education Policy (IHEP). 2000. Quality on the line: Benchmarks for success in Internet-based distance education. Available online: http://www.ihep.org/sites/ default/files/uploads/docs/pubs/qualityontheline.pdf (Accessed 7 January 2015).

Institute of Professional Editors, Australia (IPEd). 2015a. Available online: www.ipededitors.org (Accessed 11 April 2015).

Institute of Professional Editors, Australia (IPEd). 2015b. National Mentoring Program for editors: Guidance notes. Available online: http://iped-editors.org/site/DefaultSite/filesystem/ documents/NationalMentoringProgram_GuidanceNotes_17.4.15.pdf (Accessed 11 April 2015).

International Mentoring Association. 2014. Available online: www.mentoringassociation.org (Accessed 11 March 2014).

Knowles, M.S. 1970. The modern practice of adult education: Andragogy versus pedagogy. New York: Associated Press.

Knowles, M.S. 1975. Self-directed learning: A guide for learners and teachers. Englewood Cliffs: Prentice Hall/Cambridge.

Knowles, M.S. 1978. The adult learner: A neglected species. Houston: Gulf Publishing Co.

Knowles, M.S. 1984. Andragogy in action. San Francisco: Jossey-Bass.

Knowles, M.S., E. Holton and R. Swanson. 2005. The adult learner: The definitive classic in adult education and human resource development. Oxford: Butterworth-Heinemann.

Kotzé, A. 2012. Die Professionalisering van Taalpraktisyns in Suid-Afrika en Vlaandere: 'n Vergelykende Studie. Unpublished PhD thesis, North-West University.

Kouzes, J.M. and B.Z. Posner. 1993. Credibility: How leaders gain and lose it, why people demand it. San Francisco: Jossey-Bass.

Kram, K.E. 1985. Improving the mentor process. Training and Development Journal 39(4): 40-43.

Lepi, K. 2014. The key differences between summative and formative assessments. Available online: www.edudemic.com/summative-and-formative-assessments/ (Accessed 20 January 2015). 
Levinson, D.J., C.N. Darrow, E.B. Klein, M.H. Levinson and B. McKee. 1978. The seasons of a man's life. New York: Ballantine Books.

Linnegar, J.D. Forthcoming. Mentoring by any other name: A comparative study of the mentoring offerings of five professional associations of editors.

Linnegar, J.D. and I. Norenius. 2012. Mentoring: What it means. PEGboard 19(2): 3-5.

Lynn, A.B. 1998. Mentoring programs: Is there a difference in formal vs informal? Available online: http://www.lynnleadership.com/downloads/MENTORING - Formal or Informal Mentoring - Is there a Difference.pdf (Accessed 13 October 2014).

Mackenzie, J. 2011. The editor's companion. Port Melbourne: Cambridge University Press.

Manning Murphy, E. 2012. Working words. Canberra: Canberra Society of Editors.

Mossop, B. 2010. Revising and editing for translators. Manchester: St. Jerome Publishing.

Murray, M. 2001. Beyond the myths and the magic of mentoring: How to facilitate an effective mentoring process. San Francisco: Jossey-Bass.

OpEd Project. 2012. Available online: www.theopedproject.org/index.php?option =com content...id (Accessed 16 December 2012).

Passerini, K. and M.J. Granger. 2000. A developmental model for distance learning using the Internet. Computers and Education 34(1): 1-15.

Phillips-Jones, L. 2001. Guide to informal mentoring. Adapted from The new mentors and protégés: How to succeed with the new mentoring partnerships. Grass Valley, CA: Coalition of Counseling Centers (CCC)/The Mentoring Group.

Professional Editors' Group (PEG). 2013. Guidance notes for PEG mentoring scheme. Johannesburg: PEG.

Professional Editors' Group (PEG). 2014. Annual report on mentorships. Johannesburg: PEG.

Professional Editors' Guild (PEG). 2015. Available online: www.editors.org.za (Accessed 16 June 2015).

Ragins, B.R. and J.L. Cotton. 1999. Mentor functions and outcomes: A comparison of men and women in formal and informal mentoring relationships. Journal of Applied Psychology 84(4): 529-550.

Ryan, O. 2006. Mentoring new translators. Available online: http://www.proz.com/doc/574 (Accessed 16 June 2013).

Sherry, L. 1996. Issues in distance learning. International Journal of Educational Communications 1(4): 337-365. 
Sinclair, C. 2003. Mentoring online about mentoring possibilities and practice. Mentoring and Tutoring 11(1): 79-94.

Single, P.B. and C.B. Muller. 2001. When e-mail and mentoring unite: The implementation of a nationwide electronic mentoring program. In L.K. Stromei (Ed.) Creating mentoring and coaching programs: Twelve case studies from the real world of training. Alexandria, VA: American Society for Training and Development. pp. 107-122.

Society for Editors and Proofreaders (SfEP). 2012a. Mentoring. Available online: http://www.sfep.org.uk/pub/train/mentoring.asp (Accessed 9 September 2012).

Society for Editors and Proofreaders (SfEP). 2012b. FAQs: Mentoring. Available online: http://www.sfep.org.uk/pub/train/mentoring faqs.asp (Accessed 9 September 2012).

Society for Editors and Proofreaders (SfEP). 2015a. About the SfEP: Important documents. Available online: www.sfep.org.uk/pub/gen/impdocs.asp (Accessed 15 May 2015).

Society for Editors and Proofreaders (SfEP). 2015b. Annual report of the Membership Director, March 2014 to February 2015. London: SfEP.

Society for English Native-Speaking Editors (SENSE). 2015. Available online: https://www.sense-online.nl (Accessed 3 September 2015).

Sparrow, S. 2008. Coaching and mentoring: Spot the difference. Available online: http://www.personneltoday.com/hr/coaching-and-mentoring-spot-the-difference/ (Accessed 11 December 2013).

Spies, C., I. Seale and Y. Botma. In press. Adult learning: What nurse educators need to know about mature students. Curationis.

St-Jean, E. 2012. Mentoring as professional development for novice entrepreneurs: Maximizing the learning. International Journal of Training and Development 16(3): 200-216.

Tauer, S.M. 1998. The mentor-protégé relationship and its impact on the experienced teacher. Teaching and Teacher Education 14(2): 205-218.

Van de Poel, K., W.A.M. Carstens and J.D. Linnegar. 2012. Text editing: A handbook for students and practitioners. Brussels: University Press Antwerp.

Van Loggerenberg, M. 2012. Mentorship with Dr Derrick Hurlin. PEGboard 19(2): 6.

Wright, C.A. and S.D. Wright. 1987. The role of mentor in the career development of young professionals. Family Relations 36: 204-208. 